\title{
RESULTS AND COSTS OF A COMPUTER-ASSISTED IMMUNIZATION SCHEME
}

\author{
J. SAUNDERS, F.C.I.S. \\ Principal Administrative Officer, \\ West Sussex County Health Department, Chichester
}

The arrangements adopted in the West Sussex immunization scheme have already been described (Galloway, 1963; IBM United Kingdom Limited, 1966). From the details given on immunization consent forms (which are derived from birth notifications) the computer arranges appointments for child patients to attend clinics or general practitioners' surgeries, according to their parents' choice. For each clinic or general practitioner, the computer prints each month a list of patients due for a procedure and an appointment card addressed to the parents of each patient. For all clinic and some general practitioner appointments, the cards (posted direct to the patients from the County Health Department) give particulars of the dates and times of the appointments, which are normally arranged at the rate of 28 every 15 minutes. Three-fifths of the participating general practitioners (135 of a total of 222) prefer to do immunizations at their general surgeries during one week in any given month and to decide themselves how many patients should be invited to attend a particular surgery. To meet their wishes, the prepaid addressed appointment cards are sent to them so that they (or their staff) can fill in the dates and times when they wish their patients to attend. The first clinic arranged by the computer was held in Chichester in December 1962.

\section{IMMUNITY INDICES}

Before the introduction of the computer-assisted arrangements, the immunity indices in West Sussex were roughly the same as the national averages. The local indices have improved during the past six years and, by 1968, they exceeded those for England and Wales by between $16 \%$ (for diphtheria) and $47 \%$ (for smallpox) (Table I).

\section{EXPENDITURE}

Statistics of expenditure of local health authorities in England and Wales are published annually (usually in January for the previous financial year) by the Institute of Municipal Treasurers and

TABLE I

IMMUNITY INDICES

\begin{tabular}{|c|c|c|c|c|c|c|}
\hline & \multicolumn{6}{|c|}{$\begin{array}{l}\text { Percentage of Children born in Preceding Calendar Year who were Vaccinated by } \\
\text { End of Year Stated }\end{array}$} \\
\hline & 1963 & 1964 & 1965 & 1966 & 1967 & 1968 \\
\hline $\begin{array}{l}\text { Diphtheria } \\
\text { England and Wales } \\
\text { West Sussex }\end{array}$ & 65 & 69 & $\begin{array}{l}71 \\
88\end{array}$ & $\begin{array}{l}73 \\
92\end{array}$ & $\begin{array}{l}75 \\
94\end{array}$ & $\begin{array}{l}78 \\
94\end{array}$ \\
\hline $\begin{array}{l}\text { Whooping cough } \\
\text { England and Wales } \\
\text { West Sussex }\end{array}$ & $\begin{array}{l}64 \\
71\end{array}$ & 72 & $\begin{array}{l}70 \\
88\end{array}$ & $\begin{array}{l}72 \\
92\end{array}$ & $\begin{array}{l}74 \\
93\end{array}$ & $\begin{array}{l}76 \\
93\end{array}$ \\
\hline $\begin{array}{l}\text { Poliomyelitis } \\
\text { England and Wales } \\
\text { West Sussex }\end{array}$ & $\begin{array}{l}71 \\
59\end{array}$ & $\begin{array}{l}71 \\
67\end{array}$ & $\begin{array}{l}65 \\
87\end{array}$ & $\begin{array}{l}68 \\
91\end{array}$ & $\begin{array}{l}71 \\
95\end{array}$ & $\begin{array}{l}78 \\
95\end{array}$ \\
\hline \multirow[t]{3}{*}{$\begin{array}{l}\text { Tetanus } \\
\text { England and Wales } \\
\text { West Sussex }\end{array}$} & $\overline{71}$ & $\overline{71}$ & $\overline{88}$ & $\begin{array}{l}72 \\
92\end{array}$ & $\begin{array}{l}75 \\
94\end{array}$ & $\begin{array}{l}74 \\
94\end{array}$ \\
\hline & \multicolumn{6}{|c|}{ Number Vaccinated under Age 2 as a Percentage of Live Births during Previous Year } \\
\hline & 1963 & 1964 & 1965 & 1966 & 1967 & 1968 \\
\hline $\begin{array}{l}\text { Smallpox } \\
\text { England and Wales } \\
\text { West Sussex }\end{array}$ & $\begin{array}{l}17^{1} \\
28^{1}\end{array}$ & $\begin{array}{l}32 \\
57\end{array}$ & $\begin{array}{l}33 \\
76\end{array}$ & $\begin{array}{l}38 \\
83\end{array}$ & $\begin{array}{l}39 \\
81\end{array}$ & $\begin{array}{l}38 \\
85\end{array}$ \\
\hline
\end{tabular}

${ }^{1}$ Low rate due to change in recommended age for vaccination from first to second year of life 
Accountants and the Society of County Treasurers. These statistics record the expenditure incurred per 1,000 population on vaccination and immunization by each local health authority and they enable comparisons to be made with the average for England and Wales. Since the initial expenditure required to introduce the computer-assisted immunization scheme is now no longer required, the West Sussex figure has recently begun to fall, but the fact remains that, according to these statistics, the West Sussex costs were proportionately greater than the national average in each of the past seven years (Table II).

TABLE II

EXPENDITURE PER 1,000 POPULATION

\begin{tabular}{|c|c|c|c|c|}
\hline \multirow[b]{2}{*}{$\begin{array}{c}\text { Year } \\
1962 / 63 \\
1963 / 64 \\
1964 / 65 \\
1965 / 66 \\
1966 / 67 \\
1967 / 68 \\
1968 / 69\end{array}$} & \multicolumn{2}{|c|}{$\begin{array}{l}\text { England and Wales } \\
\text { (all local health authorities) }\end{array}$} & \multicolumn{2}{|c|}{ West Sussex } \\
\hline & $\begin{array}{l}f \\
32 \\
20 \\
19 \\
20 \\
22 \\
16 \\
17\end{array}$ & $\begin{array}{c}\text { s. } \\
12 \\
15 \\
191 \\
16^{1} \\
5 \\
4 \\
4\end{array}$ & $\begin{array}{c}f \\
43 \\
29 \\
38 \\
45 \\
43 \\
23 \\
19\end{array}$ & $\begin{array}{r}\text { s. } \\
3 \\
12 \\
17 \\
6 \\
10 \\
3 \\
18\end{array}$ \\
\hline
\end{tabular}

${ }^{1}$ Average for all counties (excluding Greater London)

\section{UNIT Costs}

The method of costing adopted by the Institute and the Society suggests that the West Sussex arrangements require above-average expenditure. It does not, however, take account of the fact that, in order to produce higher immunity rates, more protections per 1,000 population are now being done in West Sussex than in England and Wales as a whole. The cost-evaluation of this additional activity requires different treatment, such as a comparison of local and national unit costs. These can be calculated by dividing the total expenditure incurred in any year by the total number of protections carried out (Table III).
Tables II and III show the total expenditure incurred on equipment, tools and materials, printing, stationery and postage, local authority medical staff salaries, premises, miscellaneous expenditure and, as regards West Sussex, computer processing and programming. Neither table covers the whole cost of the immunization scheme either in England and Wales or in West Sussex. Three elements are omitted, namely the clerical costs incurred by local health authorities, by executive councils and by general practitioners. It is necessary to correct the crude unit costs given in Table III for each of these elements in order to arrive at the true unit costs.

\section{local Authority Clerical Costs}

Three clerks are employed on the computer scheme in West Sussex at a total annual cost of approximately $£ 3,000$. This outlay covers the clerical cost of all completed procedures whether undertaken by general practitioners or at local authority clinics and, when applied to the 101,955 procedures carried out in 1968, amounts to 7d. for each procedure.

According to the Department of Health and Social Security, the comparable expenditure incurred by local health authorities in England and Wales in $1968 / 69$ was $£ 138,229$. This amount was spent mainly on supporting the work undertaken not by general practitioners but at local authority clinics. The proportion of immunizations done at sucf clinics is not assessed nationally, but the records of 13 local health authorities (eight counties and five county boroughs) show that in those areas in 1968 it varied between 27 and $77 \%$ and averaged $45.4 \%$ of all procedures administered. If this percentage applied throughout England and Wales, 3,422,000 of the 7,538,000 procedures shown in Table III (line 4; column 3) were carried out at local authority clinics. If the cost of clerical support for $3,422,000$ procedures was $£ 138,229$, the cost of one procedure was 10d., and this amount should be added to the crude unit cost of 4s. 0d. for England and Wales shown in Table III.

TABLE III

LOCAL AUTHORITY EXPENDITURE PER COMPLETED PROCEDURE

\begin{tabular}{|c|c|c|c|c|c|c|}
\hline \multirow[b]{2}{*}{ Year } & \multicolumn{3}{|c|}{ England and Wales } & \multicolumn{2}{|r|}{ West Sussex } & \multirow[b]{2}{*}{$\begin{array}{l}\text { Unit Cost } \\
\text { (per completed } \\
\text { procedure) }\end{array}$} \\
\hline & Total Expenditure & $\begin{array}{l}\text { Procedures } \\
\text { Completed }\end{array}$ & $\begin{array}{l}\text { Unit Cost } \\
\text { (per completed } \\
\text { procedure) }\end{array}$ & Total Expenditure & $\begin{array}{l}\text { Procedures } \\
\text { Completed }\end{array}$ & \\
\hline 1 & 2 & 3 & 4 & 5 & 6 & 7 \\
\hline $\begin{array}{l}1965 / 66 \\
1966 / 67 \\
1967 / 68 \\
1968 / 69\end{array}$ & $\begin{array}{c}\mathbf{f} \\
1,273,000 \\
1,314,000 \\
1,079,000 \\
1,504,000^{1}\end{array}$ & $\begin{array}{l}\mathbf{6 , 4 4 1 , 0 0 0} \\
\mathbf{6 , 6 5 5 , 0 0 0} \\
\mathbf{7 , 0 8 3 , 0 0 0} \\
7,538,000\end{array}$ & $\begin{array}{lr}\text { s. } & \text { d. } \\
3 & 11 \\
3 & 11 \\
3 & 1 \\
4 & 0\end{array}$ & $\begin{array}{c}f \\
20,139 \\
19,579 \\
10,556 \\
14,844\end{array}$ & $\begin{array}{r}78,980 \\
95,291 \\
82,560 \\
101,955\end{array}$ & $\begin{array}{lr}\text { s. } & \text { d. } \\
5 & 1 \\
4 & 1 \\
2 & 7 \\
2 & 11\end{array}$ \\
\hline
\end{tabular}

1 Provisional 
Executive Council Clerical Costs

From 1 April 1967 the former Ministry of Health introduced a vaccination and immunization consent and record form (E.C.73) which general practitioners are required to complete in order to obtain vaccination and immunization payments from the executive councils. In the West Sussex scheme (with central government approval) general practitioners do not complete forms E.C.73 for persons vaccinated as a routine measure. They merely mark the appropriate column of a computer-produced clinic list and return the completed list to the County Health Department. The computer thereupon produces quarterly statements informing the Executive Council how much is due to general practitioners for the work they have carried out. In 1968 these arrangements overcame the need for general practitioners to complete 74,200 forms and, according to the Clerk of the Executive Council (Knighton, 1970), saved that Council the equivalent of one clerk, an estimated outlay of $£ 900$. In the areas of the 13 local health authorities referred to, $54.6 \%$ of all completed vaccination and immunization procedures were done by general practitioners. If this percentage applied in England and Wales, approximately 4,116,000 of the procedures shown in Table III (line 4; column 3 ) were carried out by general practitioners in 1968 . If the cost to one executive council of handling 74,200 forms E.C.73 is $£ 900$, the cost to all executive councils of handling $4,116,000$ forms is $£ 49,925$. This puts another $3 \mathrm{~d}$. On the unit cost of $4 \mathrm{~s}$. $0 \mathrm{~d}$. shown in Table III.

\section{General Practitioner Clerical Costs}

In his general practice, Newmark (1970) estimates that it takes about 25 minutes to complete 10 forms E.C.73. If this calculation is applied to the estimated $4,116,000$ forms completed by general practitioners in 1968, no fewer than 94 full-time clerks are required to do the work. If each is paid $£ 900$ a year, the total annual expenditure is $£ 84,600$ and this is equivalent to a further $5 \mathrm{~d}$. on the unit cost of $4 \mathrm{~s}$. $0 \mathrm{~d}$. shown in Table III.

The crude unit costs in 1968/69 for England and Wales and West Sussex may therefore be corrected to take account of the actual expenditure incurred on clerical work by local health authorities, by executive councils and by general practitioners (Table IV).

\section{COMPUTER System-Design ANd TAKe-ON Costs}

The lower unit cost in West Sussex in 1968/69 compared with that in England and Wales has been established only after several years' experience of the computer-assisted arrangements. In order to
TABLE IV

CORRECTED UNIT COSTS: $1968 / 69$

\begin{tabular}{|c|c|c|}
\hline & England and Wales & West Sussex \\
\hline $\begin{array}{l}\text { Crude unit cost (Table III) } \\
\text { Local authority clerical cost } \\
\text { Executive council clerical cost } \\
\text { General practitioner clerical cost }\end{array}$ & $\begin{array}{rr}\text { s. } & \text { d. } \\
4 & 0 \\
10 \\
3 \\
\\
5\end{array}$ & $\begin{array}{rrr}\text { s. } & \text { d. } \\
2 & 11 \\
& 7 \\
\end{array}$ \\
\hline Corrected unit cost & 56 & 36 \\
\hline
\end{tabular}

produce the financial economies which are now demonstrable, expenditure had to be incurred on

(a) the design of the computer system (estimated at $£ 5,000)$;

(b) transferring manually-maintained records to computer storage. Four additional staff (three clerks and a punch operator) were employed for a period of three years $(1963 / 65)$ at a total annual cost at present levels of approximately $£ 4,000$; and

(c) abortive machine time. When the immunization records, particularly those kept by general practitioners, were transferred to computer storage, attention was drawn immediately to a considerable number of inaccuracies. The computer produced appointment cards for immunizations which parents said had already been given, and many cards were sent to people who had long since changed their home addresses. Inevitably, the computer was blamed for the mistakes which were made! The cost of this abortive machine time was about $£ 1,800$ annually for the three-year take-on period.

The total cost of the design of the computer system and of transferring to computer storage the manual records kept by general practitioners and clinics was therefore about $£ 22,400$; this was spread over a period of three years.

\section{Discussion}

Experience in this study shows that the use of a computer in the management of a vaccination and immunization scheme for a child population of about 100,000 has resulted in a unit cost for each completed immunization procedure of $3 \mathrm{~s}$. $6 \mathrm{~d}$., which is $36.4 \%$ cheaper than the comparable unit cost for England and Wales (Table IV).

In order to produce this economy, additional expenditure of approximately $£ 22,400$ was required by the County Council to effect the transition from a manual to a computer system of working. If the present unit cost in West Sussex were the same as in England and Wales, the additional annual cost to the National Health Service of the county's immunization scheme would be $£ 10,196(101,955 \times 2 \mathrm{~s}$. $)$. The initial system-design and computer take-on 
costs are therefore recoverable within about two years of the completion of the transitional period.

Apart from the item-of-service fees paid to general practitioners by executive councils, the total cost to the National Health Service (i.e., to local health authorities, executive councils and general practitioners) of vaccination and immunization throughout England and Wales would appear to be $£ 2,072,950$ (i.e., 5s. 6d. (Table IV) $\times 7,538,000$ (Table III)). If the West Sussex arrangements were introduced nationally, the cost would be $£ 1,319,150$, a reduction of $£ 753,800$. In order to achieve this reduction (since the child population of England and Wales is 111 times greater than that of West Sussex) a national outlay of about $£ 2,486,400$ would be required. This could be reduced by about $22 \%$ if the same computer system were used throughout the country, or by a smaller percentage if groups of local health authorities cooperated in the establishment of their own systems. The initial development expenditure would in any case be recoverable in cheaper unit costs within two to three years after the introduction of the computer scheme had been completed, and there would thereafter be a continuing annual saving of about $£ 750,000$.

Since it would no longer be necessary to store millions of personal record cards, further reductions in expenditure would result from savings on office accommodation. During a period of continuing financial inflation, computer usage would, moreover, contribute to a less rapid growth in future expenditure because machine costs are likely to remain more stable than staff salaries.

A computer-assisted immunization scheme produces high levels of immunity (Table I). These result in fewer notifications of infectious disease and further financial economies brought about by fewer general practitioner consultations and fewer admissions to hospitals. It seems that a system has in fact been devised which will virtually eliminate disease for which there is an effective antigen from any literate community which has a reasonably efficient postal system. Few parents refuse to have their children protected if they are told individually and in plain language what is being offered and if, when a procedure is due, they receive a written invitation to keep a timed appointment at a service source (general practitioner or clinic) of their own choice. Since computers are capable of mopping up all routine clerical work, they are eminently suitable to do this work and, if programmed properly, their memory (unlike that of human beings) is infallible. This is illustrated by the smallpox vaccination rate in West Sussex compared with that in England and Wales (Table I). The recommended age for such vaccination is during the second year of life. Computers do not forget this. It seems that human beings do, and it is sad to reflect that one result of changing the recommended age was to depress the national acceptance rate from $48 \%$ in 1961 to $32 \%$ in 1964 .

All children are brought within the computer scheme at birth or when their families move to West Sussex, and all have therefore an equal opportunity of taking part in the arrangements; their ability to resist preventable disease is not left to chance by depending, for example, upon their parents' response to public notices or to general invitations conveyed orally by doctors and nurses. With a scheme of this kind, conventional health education (posters, leaflets, lectures and discussions) aimed at persuading parents to have their children immunized can safely be abandoned, as it was in West Sussex some years ago with a further, though small, saving in cost. Few people react spontaneously to a message on a poster; fewer fail to reach a decision when faced personally with clear alternatives regarding their children's health and future welfare.

Vaccination and immunization schemes operate under a statutory authority which requires every local health authority to make arrangements for protection to be offered against certain diseases and 8 these arrangements must give general practitioners the opportunity to participate. Before the computero scheme was started in West Sussex in 1962, such? arrangements as did exist left the various participants to do the best they could with little, if any, administrative support. It was only after the introduction of central management and control of the scheme for the whole county that the immunity indices began to improve. This is not an argument for centralized control of all personal services, but it is an illustration of what can be achieved without loss of individual choice and professional independence. Parents remain entirely free to decide whether to accept a personal invitation to have their children protected against disease and, having accepted such an invitation, they remain equally free to decide whether the various procedures shall be carried out by their own doctor or at a local authority clinic. They are, however, relieved of the need to remember when these procedures shall be done; the computer sends them a reminder at the appropriate time. Similarly, the independence of the general practitioner remains undisturbed. He decides whether to take part in the local health authority's arrangements. Having decided to do so, it remains entirely up to him to administer the procedures either during his ordinary surgery hours or during a set period each month when, with the help (if he decides he needs such help) of the local authority nursing staff attached to his 
practice, he will immunize all patients on his list who are due for a procedure to be carried out. If the West Sussex experience is typical of the country as a whole, only one doctor in every 223 will prefer to operate his vaccination and immunization arrangements on an eyeball-cerebral-manual basis.

\section{SUMMARY}

The use of a computer during the last seven years in the management of the West Sussex immunization scheme has produced a unit cost which is cheaper than the average for England and Wales. The financial benefits are shared by the local health authority, the executive council and the general practitioners. It is suggested that similar economies could be reproduced nationally. Reference is made to other benefits of the West Sussex arrangements, including the immunity levels attained, which are now the best in the country (Godber, 1969).

For his encouragement and for helpful suggestions I am grateful to Dr. T. McL. Galloway, County Medical Officer of Health of West Sussex. I am indebted to my former colleague in West Sussex, Dr. A. H. Snaith, and to Dr. Michael D. Warren of the London School of
Hygiene and Tropical Medicine for constructive comment and advice, and I thank Mr. C. Ferns, Group Accountant in the West Sussex County Treasurer's Department, for checking my calculations. For some of my source material I have relied on the Digest of Health Statistics published by the Department of Health and Social Security (1969) and I gratefully acknowledge the assistance I have had from several officers of that Department.

\section{REFERENCES}

Department of Health and Social Security (1969). Digest of Health Statistics for England and Wales, 1969. H.M.S.O., London.

Galloway, T.MCL. (1963). Management of vaccination and immunization procedures by electronic computer. Med. Offr, 109, 232.

GodBer, G. E. (1969). On the State of the Public Health. The Annual Report of the Chief Medical Officer of the Department of Health and Social Security for the year 1968. H.M.S.O., London.

IBM UNITED KINGDOM Limited (1966). The prevention of disease. A 15-minute 16-mm sound film made in association with West Sussex County Health Department.

KNIGHTON, J. R. (1970). Personal communication.

Newmark, R. W. (1970). Personal communication. 